\title{
EXPLORING THE INTERPLAY OF MASS ATROCITIES AND EMOTIONS
}

DOI: $10.20542 / 2307-1494-2020-1-178-180$

Emotions and Mass Atrocity: Philosophical and Theoretical Explanations. Ed. by T.Brudholm and J.Lang. - Cambridge: Cambridge University Press, 2018. $306 \mathrm{p}$.

Mass atrocities are not just concrete actions but happen also inside people's minds in the form of thoughts and emotions. The book tries to explain the interplay between atrocities and emotions. Study of emotion or affect in general has become a part of research in social sciences relatively recently, during the past two decades. The approach of the book is largely philosophical and psychological. Of the editors of the book, Thomas Brudholm (University of Copenhagen) specializes in philosophy, while Johannes Lang (Danish Institute for International Studies) is a researching on social psychology of war. Other authors come from various backgrounds, including history, sociology, and political science. The cultural background of most of the authors is western.

In the book, "mass atrocity" is defined as political violence that violates international law and includes war crimes, crimes against humanity and genocide. These crimes have been defined in more detail in international norms, such as the Rome Statute of the International Criminal Court.

Emotions are seen as present in the actual deed of atrocity, in the structures and ideologies that give rise to atrocity and in the psychological and social-psychological mechanisms that operate afterwards. These three situations are reflected in the structural composition of the book that consists of three parts. 13 chapters of the book are divided thematically in chapters that focus on causes and dynamics of atrocities, emotional responses to atrocities and repair and commemoration after atrocities.

The first part of the book is about the causes and dynamics of mass atrocity. In Chapter 2, David Konstan, Professor of Classics at New York University, notes that the concept of genocide has been known since classical antiquity. He defines some basic terminology by stating the difference between hate, anger and the concept of so-called "disgusting other". He notes that in ancient Greece there was a casual attitude towards mass atrocity, which meant, inter alia, that the enemy did not need to be demonized or hated as a group to be slaughtered in large scale.

In modern times, where at least some level of respect towards basic human rights is widely expected, more is needed for humans to be able to kill other humans in large numbers. As Neta Crawford, professor of political science at Boston University, notes in Chapter 3 , genocide is a policy choice that requires mobilization of people. She claims that an intention to commit genocide requires three things: specific emotions, a political legitimation crisis, and militarism. Typically the potential perpetrators feel fear and hate towards their potential group of victims. Fear can be used as a source of hate that can then be mobilized to action, especially if the hated and feared other can be seen as an existential threat in times of legitimacy crisis for political leaders. Militarism adds to the equation by promising security by a military solution. In general, Crawford argues, genocide follows from the institutionalization of fear and hope: fear for a certain group of people and hope that things will be better after eliminating that group.

What makes Crawford's thinking especially interesting is how close the way of thinking that she depicts is to the thinking of some prominent populist politicians in different countries. It is not unusual for hardline politicians in their speeches and social media postings to depict groups of people as existential threats. These arguments can be seen, for example, when the president of the Philippines, Rodrigo Duterte, talks about 
the people he labels as drug dealers, or when politicians of the European far right talk about refugees from the Middle East as rapists and terrorists. In both cases, a minority outgroup is seen as a collective threat to a majority.

Pride can also play a part in genocide, notes Johannes Lang in Chapter 4. According to him, a collective pride drove Nazi perpetrators of the Holocaust. In their indoctrination, pride was induced in them by introducing an idea that mass killing of certain people was a difficult but necessary task that only the hardest men were able to do.

In Chapter 5, Thomas Brudholm and Birgitte Schjepelern Johansen (University of Copenhagen) write about hatred. Like Crawford in Chapter 3 and Arne Johan Vetlesen from Oslo University in Chapter 6, Brudholm and Schjepelern Johansen make a connection between existential fear and hatred. They also discuss so-called hate speech, making an interesting point that hatred can be made present in linguistic speech without anyone actually feeling hatred. According to them, hate can be an attitude, not just an emotion.

The second part of the book is dedicated to emotions caused by atrocity. In Chapter 7, professor of political philosophy at the University of Verona, Adriana Cavalero, writes about shame. She makes an interesting distinction between horror and terror, in reference to a philosopher and political theorist Hannah Arendt. While terror means frightening people into submission, horror is essentially pointless and inexplicable. Cavalero also refers to the Holocaust survivor Primo Levi, according to whom the Soviet soldiers who liberated the concentration camp of Auschwitz felt horror, which in turn provoked shame in them. According to Levi, the shame of the soldiers was the same shame that the inmates of the camp felt, "the shame that the just man experiences at another man's crime".

Survivor shame is discussed also in chapter 9 by Alba Montes Sanchez and Dan Zahavi from the University of Copenhagen. They make a connection between shame, self-identity and group identification. In Chapter 8, philosopher Ditte Marie Munch-Jurisic from University of Roskilde discusses the disgust that a perpetrator of mass atrocity feels. She argues that disgust is not an effective moral response against genocide but can, on the contrary, cultivate genocidal mentality, because the ability to manage disgust becomes part of the self-understanding of the perpetrators.

Andrew Ross from Ohio University discusses the role of emotions in humanitarian politics in Chapter 10. He argues that policies towards humanitarian events, including mass-casualty acts or campaigns of violence, can be explained by emotions. He argues that even the U.S. decision to invade Iraq in 2003 was still partly driven by the outrage among American public towards the attacks of September 11, 2001.

Part three of the book deals with what happens after atrocity. In Chapter 11, the philosopher Margaret Urban Walker writes about hope - an emotion that, according to her, is essential in the repair work after genocide. She defines hope as an orientation towards a future that is in some desired respect open to what we value. She also notes, however, that speaking of hope after genocide can also in some circumstances be irrelevant or irresponsible.

Jeffrey Blustein of the City University of New York covers psychopathologic effects of genocide on its victims in Chapter 12. According to him, trauma resulting from a natural disaster is fundamentally different from trauma resulting from an atrocity committed by humans. The difference, according to him, is that atrocities committed by humans question the assumption of moral equality of people. Having covered both political violence and natural disasters as a journalist, the author of this review finds this distinction relevant.

The main point of Blustein's article is, however, that getting on with life after genocide is not about forgetting but about arranging memories to a new equilibrium. He 
stresses that not only individuals but also entire communities can be traumatized by atrocities. Like individuals, communities can mourn their losses and manage their anger, rearranging their memories to become so-called narrative memories instead of traumatic memories. Quoting psychiatrist Vamik Volkan, Blustein warns that while raising monuments as a means of collective mourning can make it easier for members of the community to work through their losses, it can also keep people stuck in the mourning and give rise to feelings of revenge. Blustein's idea of collective trauma seems to be related to the concept of "collective unconscious" in Jungian psychoanalysis. Blustein does not explicitly refer to Carl Jung, but he does refer to Volkan who is a psychoanalytically oriented psychiatrist.

One of the most thought-provoking chapters is the last one, where philosopher Nir Eisikovits (University of Massachusetts) ponders embarrassment and shame in international relations. According to him, countries can be made to change their policies by embarrassing them. One of the examples he mentions is how the United States ultimately had to take the civil rights agenda of Martin Luther King seriously during the Cold War. Eisikovits notes that the Cold War was also a philosophical competition between the United States and the Soviet Union, and that in the competition the United States had to live up to the human rights standards it had made such a central part of its national self-identity. Not respecting civil rights would have been embarrassing.

Overall, the approach of the book is theoretical, while empirical research is present only in occasional references. There is theorizing around things like whether or not emotion needs or includes cognition, and if it does, which comes first, emotion or cognition. For a non-philosopher, this kind of pondering feels somewhat misplaced.

Still, the book as a whole is highly relevant. It makes clear that the dichotomy of "rational" versus "emotional" does not help much in explaining most human activity. Even grave human rights violations cannot be seen as either purely rational, or irrational. It is important to know that when we think that we are making rational judgments, there are always unconscious factors at play. Sometimes they might be called gut feelings, sometimes perhaps prejudice.

The book also helps understand human activity in more general terms. The first part of the book in particular gives an insight into mechanisms that can activate genocidal policies or can be manipulated to activate such policies. To a certain extent, these mechanisms seem to be also applicable to less violent populist policies that increasingly surface in many countries.

Mikko Paakkanen*

\footnotetext{
* Mikko Paakkanen (Finland) - foreign affairs journalist, M.A. in Social Sciences and visiting student at European University at Saint-Petersburg.

Микко Пааккинен (Финляндия) - журналист-международник, стажер Европейского университета в Санкт-Петербурге.
} 